\title{
The Learning Model of Flood Disasters Mitigation Based on Local Culture for Early Childhood in Bengawan Solo River Basin
}

\author{
Siti Wahyuningsih \\ Early Childhood Department \\ Universitas Sebelas Maret \\ Surakarta, Indonesia \\ siti_w@staff.uns.ac.id \\ Muh. Munif S \\ Early Childhood Department \\ Universitas Sebelas Maret \\ Surakarta, Indonesia \\ wandamunif@yahoo.com
}

\author{
Warananingtyas Palupi \\ Early Childhood Department \\ Universitas Sebelas Maret \\ Surakarta, Indonesia \\ palupi@staff.uns.ac.id \\ Adriani Rahma \\ Early Childhood Department \\ Universitas Sebelas Maret \\ Surakarta, Indonesia \\ adriani.rahma@staff.uns.ac.id
}

\author{
Ruli Hafidah \\ Early Childhood Department \\ Universitas Sebelas Maret \\ Surakarta, Indonesia \\ ruli_hafidah@yahoo.com \\ Nurul Kusuma Dewi \\ Early Childhood Department \\ Universitas Sebelas Maret \\ Surakarta, Indonesia \\ kusuma.dewi@staff.uns.ac.id
}

\begin{abstract}
This article aims to describe the learning model based on the local culture for early childhood. The study used an action-based qualitative approach. The research target was 27 children aged 5-6 years. The research was conducted at PAUD Garuda and TK Aisyiyah Gandekan Surakarta, located in Bengawan Solo river basin. Data collection techniques used semi-structured interviews, observation, and documentation. Data analysis used Miles and Huberman interactive models. The data were analyzed in accordance with Miles and Huberman procedures using content analysis models. As a result of the research, it is possible to formulate the findings that flood disaster mitigation learning which is based on local culture, provide children' interests and excitement in accordance with their basic nature of playing. The results of this study also make children regardless of the pressure and fear of their soul through traumatic healing from the flood disaster that always comes.
\end{abstract}

Keywords - mitigation learning, flood disaster, traditional game, local culture

\section{INTRODUCTION}

The geography of Indonesia is an archipelagic country and in the percentage of countries, Indonesia is a country prone to natural disasters, especially Java. One of the disasters that often occur on the Java island is a flood disaster. Flood is an overflow of water beyond the normal limits that occur suddenly and is damaging to property, objects, livestock, and plants in their environment [1],[2],[3].

Surakarta is one of the cities in the Java island which is in a geographical area that is prone to floods. One area with a high level of disaster hazard according to the data from BPBD is Gandekan Village, Jebres sub-district, Surakarta City. This area is directly adjacent to Pepe river and the Bengawan Solo embankment on both sides. According to information from community leaders in the Gandekan region from 1967 to 2018, there were around 4 times of the major floods that occurred and drowned the houses and facilities of the citizens, even taking the wounded and dead. This densely populated area is inhabited by around 7500 inhabitants and around $13 \%$ of its citizens are between the ages of $0-18$ years. In these regions, there are several schools to fulfill the educational needs of citizens, two of which are PAUD Negeri Garuda and TK Aisyiyah Gandekan.

The flood disaster certainly has an impact on the lives of the Gandekan community, including among the early childhood, such as learning activities in those schools that are hampered, dirty environment accompanied by illness suffered after the flood. Early childhood who lives in a floodprone environment must be given adequate life skills as an effort in disaster mitigation in their area. This research is also expected to contribute to educators and observers of PAUD/TK to provide interventions related to disaster mitigation as an alternative to prepare children in difficult situations as a result of disasters.

The benefits of holding disaster mitigation for children is to reduce the direct effects of childhood trauma on disasters, especially in earthquake disasters [4]. It can give the benefit of disaster mitigation for early childhood is that children can understand the actions that must be taken when a disaster occurs [5]. The benefits of disaster mitigation for early childhood is to reduce the risk of disasters that can befall children in the form of direct effects, namely trauma to disasters, and children can understand what actions should be taken when a disaster occurs.

The design of education for early childhood, especially in the learning process is flexible and can be applied to various situations and conditions. In flood-prone areas early childhood learning models based on disaster mitigation are very important, in addition to providing knowledge to children can also prepare children when the flood disaster comes. Disaster mitigation-based learning in early childhood will be more meaningful if learning itself is done contextually relating to local wisdom in the area where children live. Thus, children will have knowledge about flood disasters both in response, during disasters, and after the flood disaster.

\section{METHOD}

The study was conducted at PAUD Garuda and TK Aisyiyah, Gandekan village, Surakarta. This study used a qualitative approach with a single case study type. The 
subjects of this research are early childhood in PAUD Garuda and TK Aisyiyah Gandekan, Surakarta. These subjects are located in the Bengawan Solo river basin. Data sources in this study are early childhood, teachers, parents, the surrounding community, local government, and experts related to flood disasters mitigation. Data collection techniques used interview, observation, and documentation techniques. Interview techniques were conducted on teachers, parents, the surrounding community, local government, and experts related to flood disasters mitigation $(B P B D$ and $Y A K U M)$.

The interviews used Focus Group Discussion (FGD) techniques that aimed at obtaining information about flood disasters and local culture during the floods in the Gandekan area. Observation techniques were carried out in the early childhood at PAUD Garuda and TK Aisyiyah Gandekan to find out the learning process. Documentation techniques were used in the form of the photo, video, and document. Documentation techniques were used to document data or information related to the research. The validity test of research data used to source and technique triangulation, which the data focus were checked again by using various data collection techniques and from several research sources so that it will show the same data. Research data analysis used data analysis of the Miles and Huberman model which includes data collection, data reduction, data presentation, and verification of research data.

\section{RESULT}

Disaster mitigation is a series of efforts undertaken to reduce disaster risk, physically and structurally through the creation of physical and non-structural buildings through awareness and capacity building to face disaster threats. Mitigation can also be interpreted as a preparedness effort that is a series of planned and programmed activities to prepare themselves both when there is a threat of disaster or not.

Mitigation activities should ideally be a synergy between the government (National Disaster Management Agency / BNPB, District Disaster Management Agency/BPBD, Village government, and other related institutions), community, and business world. In accordance with the statement of the Head of the BPBD of Surakarta: "Mitigation activities are a synergy between the government, the community, and the business world. The symbol of BPBD is in the form of a triangle, which means the synergy between the three components."

Types of disaster mitigation activities can be divided into two, namely structural and non-structural mitigation. Structural mitigation can be in the form of the construction of a special canal for flood prevention, the making and installation of early detection tools for the arrival of floods, or making higher buildings so that they are not flooded during floods. Structural mitigation has been carried out in the Bengawan Solo River Basin (DAS), especially in the Gandekan Sub-district, where the government has built dikes along the banks of the Bengawan Solo River and the tributaries of the Bengawan Solo River and elevated several houses and schools. This was reinforced by the narrative of one of the community leaders in Gandekan:

"A high foundation and embankment were built in the small sluice gates and several residents' houses were elevated to the floor of their houses so that at times floods would not be flooded into the house. Likewise with school buildings like PAUD Garuda."

On the other hand, non-structural mitigation has also been implemented as an effort to reduce the impact of flood disasters. One of the efforts that have been carried out is the program from the BPBD of Surakarta which provides regular counseling and training on first aid in flood disasters. This was as stated by the Head of BPBD of Surakarta:

"We periodically, routinely carry out training activities, which can be followed by anyone, especially those who can be directly affected by the flood. An example of the training material is how do not sink and how to save themselves when a flood occurs."

Mitigation activities cannot be separated from contingency. Contingency is a tool to save ourselves in the event of a disaster in the area. Communities can use objects in the surrounding environment, for example, certain plants that are widely available in the area to make certain tools to save themselves. This was conveyed by a team member from the BPBP of Surakarta: "Mitigation cannot be separated from contingency, namely tools to save themselves in the surrounding environment such as if there are a lot of bamboos in a certain area, then, for example, these bamboos can be used to make rafts when floods come."

In Gandekan area, people have also done this, they use banana steam to make gethek, it likes to boat. This is in accordance with information from a community member: "We usually use banana steam to make gethek during floods, because there are many banana trees in this area."

Besides contingency, another thing that needs to be considered in disaster mitigation activities is a vulnerability. The vulnerability is a condition that explains physical, economic, social, political and behavioral or attitudinal factors that reduce the human ability to be ready to face disaster hazards.

The highest level of vulnerability is among children under five years old, followed by children of kindergarten and elementary school age, elderly people, and women. Kindergarten students as one of the vulnerable parties in the disaster, also need to get an education based on disaster mitigation, especially floods because they live in flood-prone areas. For children, disaster mitigation-based on education aims to train children preparedness, which includes providing information to children about threats and disasters, things that must be done and avoided before a disaster occurs, when a disaster occurs, and after a disaster, ways to save ourselves if a disaster comes, as well as setting or maintaining the environment to reduce the threat of disaster.

Flood disaster mitigation education must be given since early education, namely in early childhood. Flood disaster mitigation education can be carried out in the daily learning process which knowledge concepts and flood themes are included in learning materials with contextual activities in accordance with the environment and culture around the children.

Flood disaster mitigation education which is given to children aims to provide concepts of knowledge about floods, instill behavior in healthy living, build a character of love for the environment, and prepare children when the disaster comes. Education for flood disaster mitigation in 
early childhood is carried out through learning activities. The learning principles in early childhood include: (1) the orientation of the children needs, (2) learning through play, (3) creative and innovative learning, (4) a conducive environment, (5) using integrated learning, and (6) developing life skills.

\section{DISCUSSION}

According to the Ministry of National Education in carrying out the learning process in early childhood, an educator must be able to facilitate children needs, stimulate all aspects of childhood development, develop life skills, instill character, and build children's knowledge through fun play activities. In addition, learning activities can also be carried out in an integrated thematic learning by utilizing media and learning resources around children. The concept of learning in early childhood is through playing, placing children as subjects and teachers and parents as facilitators [6].

Activities using media and resources around the children and the educators are learning facilitators. Flood mitigation learning based on local culture can be one of the models for early childhood learning to provide flood material, so that early childhood can get information about flood threats and disasters. it includes things that must be done and avoided before a disaster occurs, in the event of a disaster, and after a disaster, ways to save ourselves if a disaster comes, as well as environmental management or maintenance to reduce the disaster threat. The design of flood disaster mitigation learning models based on local culture can be done in several stages, namely: 1) determine themes, 2) develop material, and 3) arrange the learning activities.

\section{1) Determine themes}

The first stage in the flood disaster mitigation learning model based on local culture for early childhood is to determine the theme of learning. The theme is a reference point in developing material, topics, and knowledge that will be given to children. The learning theme used in this flood disaster mitigation learning model can be taken from the 2013 curriculum.

The foundation for determining the theme can be adapted from the children immediate environment so that children can learn concretely and contextually from the closest thing to the child. As the result, children can know the simple thing to a more complicated one. The theme must be based on the children needs, interests, and the environment. Some themes that can be used in disaster mitigation learning models are like self, environment, plants, animals, the universe, etc.

\section{2) Develop material}

The second stage is developing the material. The material in this learning model is the knowledge of various flood information, such as causes and effects of floods, ways of handling floods, how to deal with floods, etc. The developed material must also be adjusted to the theme and aspects of childhood development. The material development can be done by looking at the core and basic competencies in the 2013 curriculum which will then be presented in RPPH (Daily Learning Plans) which will be detailed in the indicators of children development.

\section{3) Arrange Learning Activities}

Learning activities are based on the developed themes and materials. These learning activities are made by utilizing media and learning resources around children. Flood disaster mitigation learning activities are made by developing local vulnerabilities in the children's environment, such as cultural tools, traditional songs, traditional games, traditional values, etc. which are related to flood material. The learning activities can also be done with various methods, namely field trips, playing, singing, projects, drama, etc. The following are examples of developing themes, materials, and learning activities for flood disaster mitigation based on local culture for early childhood.

The implementation of flood disaster mitigation learning based on local culture in early childhood is inseparable from the role of adults (teachers, parents, community, and government). Each of these human resources has an important role in building the children knowledge by using the Among system (asah, asih, asuh) so that children gain not only knowledge but also life skills and character values which are obtained from adults.

In addition, the application of the among system in the learning of flood disaster mitigation based on local culture in early childhood is one way to stimulate all aspects of childhood development, introduce science and technology, and preserve local culture. The attitude of Asah, Asih, Asuh: Asah that is directed to the cognitive aspect is sharpening, interpreted as sharpening to be pointed or shiny [7].

In the learning activities process are defined as essential and meaningful activities. Thus, through learning flood mitigation based on local culture, children will have healthy life behaviors and safety behaviors as well as attitudes of preparedness related to flood disasters. This flood disaster mitigation learning model based on local culture for early childhood can also be applied by parents at home and the community.

This is in accordance with Ki Hajar Dewantara's opinion about the three lives of children, namely family, community environment, and school [8]. Through the application of these three children's lives, it is hoped that children can build knowledge, life skills, and character values in nurturing the environment and helping others. This is also supported by Aristotle's' opinion, namely, a good character as living with the right behavior in terms of relating to others and relating to oneself [9].

So that through learning that involves various roles of human resources, interacting directly with the environment, and using local culture as a medium and source of learning for children, they will easily build self-concept and sensitivity to the environment around them.

\section{CONCLUSION}

The results of this study indicate that flood disaster mitigation education can be carried out in the daily learning process that the knowledge concepts and flood themes are included in learning materials with contextual activities in accordance with the environment and culture around the children. The implementation of flood disaster mitigation learning based on local culture which uses the principles of Ki Hajar Dewantara's education about the among system begins with determining themes, developing learning 
materials about the flood concept, and arranging activities using media and resources around children.

The educators have roles as facilitators to accompany children growth and development, help to build children knowledge, and instill the children's character value. The model of flood disaster mitigation learning based on local culture for early childhood can also be applied by parents at home and the community. It means that the result of this research can be important for them. Besides the results of this study become important for teachers because the implementation of the flood disaster mitigation learning model based on local culture in learning activities can help to build children's knowledge and instill the children's character values. This is in accordance with $\mathrm{Ki}$ Hajar Dewantara's opinion about the three lives of children, namely family, community environment, and school. Through the implementation of the three children's lives, it is hoped that children can build knowledge, life skills, and character values in nurturing the environment and helping others.

\section{REFERENCES}

[1] Arief, A. Hutan dan Kehutanan. Yogyakarta: Penerbit KANISIUS. 2001.

[2] Kodoatie, R. J. Rekayasa danManajemen Banjir Kota.Yogyakarta: ANDI OFFSET. 2013

[3] Landesman, L. Y. Public Health Management of Disasters. Washington DC: APHA PRESS. 2012.

[4] Oncu, E. C., \& Wise, A. M. The Effects of the 1999 Turkish Earthquake on Young Children. Traumatized Children's Completion of Short Stories,1161- 1175. 2010

[5] Wulandari , N. P. Implementasi SistemPembelajaran Mitigasi Bencana di Sekolah Siaga MIN Jejeran Wonokromo Pleret Bantul. Universitas Negeri Yogyakarta ,Fakultas Keguruan dan Ilmu Pendidikan.Yogyakarta: Universitas Negeri Yogyakarta. 2015.

[6] Susanto, A. Pendidikan Anak Usia Dini. Jakarta: Bumi Aksara. 2017.

[7] Fudyartanta, K. Membangun Kepribadian Dan Watak Bangsa Indonesia Yang Harmonis Dan Integral.Yogyakarta: Pustaka Pelajar. 2010.

[8] Dewantara, K. H. Pendidikan. Yogyakarta: Taman Siswa. 1997.

[9] Lickona, T. Pendidikan Karakter (alih bahasa: Lita S). Bandung: Nusa Media. 2013. 